\title{
Inclusive Institutions - a Precondition of Sustainable Development. A Comparative Analysis Between Romania and Poland
}

\author{
By Oana-Ramona Socoliuc (Guriță) $)^{1}$, Ion Pohoață², Delia-Elena Diaconașu ${ }^{3}$
}

\begin{abstract}
When trying to identify the sources of growth and sustainable development, institutions and their effectiveness are among the most important and powerful instrument required to explain the economic dynamics of countries all over the world. More precisely, those rules, formal or informal, political or economic, that foster the participation of the majority of people in activities able to ensure the allocation of resources to their most productive destinations are the ones that promote long-term prosperity. Their significance is becoming even more important when the particular case of transition economies is addressed. Consequently, the aim of this paper is to demonstrate that inclusive institutions (political and economic ones) are a prerequisite for the long-run development, mainly for emerging economies. Using an unique dataset of indicators that highlight the quality of economic and political institutions we have employed a VEC Model, variance decomposition and Granger causality analysis for Romania and Poland, in order to emphasize that, from a comparative perspective, each transition path towards the market economy has designed different rules of the game determining, thus, dissimilar development profiles.
\end{abstract}

Keywords: Sustainable development, Transition economies, Institutions, Institutional performance

\section{Introduction}

From the Brundtland Report published in 1987, concerns related to sustainability have expanded from the environmental issues to economic, social and political dimensions. Sustainable development was then defined as "a process of change in which the exploitation of resources, the direction of investments, the orientation of technological development, and institutional change are made consistent with future as well as present needs" (World Commission on Environment and Development, 1987, p.17). Consequently, when the topic of sustainable economic development is addressed, the standard economic perspectives of growth and prosperity remained unable to explain the existent development discrepancies between nations worldwide. However, the theory of the New Institutional Economics (NIE) came to fill this gap and to provide the necessary explanatory forces for the economic dynamics of countries, without neglecting sustainability dimensions. Generally, institutions can be defined as "systems of

|' ${ }^{1}$ ecturer at "Alexandru Ioan Cuza" University of Iasi, Romania, Faculty of Economics and Business Administration, Department of Economics and International Relations.

2Professor at "Alexandru Ioan Cuza" University of Iasi, Romania, Faculty of Economics and Business Administration, Department of Economics and International Relations.

${ }^{3}$ Scientific Researcher at "Alexandru Ioan Cuza" University of Iasi, Romania, Faculty of Economics and

Business Administration, Department of Research. 
established and embedded social rules that structure social interactions" (Hodgson, 2006, p. 18) or "rules of the game in society or, more formally, are the humanly devised constraints that shape human interaction (North, 1990, p.3). They have the role of reducing uncertainty and encouraging human cooperation, therefore, they play a major role when dealing with sustainability, given their large areas of action. Irrespective of their nature, formal or informal, rules are the ones that "structure incentives in human exchange, whether political, social, or economic" (North, 1990, p.5).

In this paper we are interested in highlighting the role of inclusive institutions on longterm development for the example of two countries that had to construct primarily healthy political institutions which afterwards should promote inclusive and efficient economic rules. But, as Thorstein Veblen has pointed out, institutions can be good or imbecile (Veblen, 1992), depending on the interests of those who have the power to impose them, namely, the political class. In other words, political regulators are responsible for determining the capacity of economic institutions to trigger and boost sustainable development, or, on the contrary, to further maintain poverty. Such perspective is on the same wavelength with the World Commission on Environment and Development which stated that "in the final analysis, sustainable development must rest on political will" (p.17). Starting from such premises, the aim of the paper is to show that inclusive institutions (political and economic ones) are a starting point for the longterm development, especially when the case of former USSR economies is targeted, by using a comparative applied analysis to Romania and Poland. Today's reality is showing us that in Poland political will managed to create inclusive political and economic institutions, while Romania was confronted with multiple challenges in this respect for the last three decades affecting, thus, the prosperity of the country on the long-run. The reasons of limited progress made by Romania in terms of sustainable economic dynamics are deeply rooted in the ineffective economic and political institutions. The research objectives of the paper are: (1) to define and provide a clear theoretical framework concerning the good and effective institutions, well-known today as inclusive institutions, and how can they support sustainable development; (2) to highlight that especially for those countries which have experienced centralization in the past, the creation process of a new institutional foundation with a particular focus on inclusive and not extractive rules of the game was vital for a sustainable transition towards the market economy; (3) to demonstrate from a theoretical and empirical perspective that current development of Romania and Poland are determined precisely by the quality of their internal institutions (mainly extractive for Romania and most of them inclusive for the case of Poland); and (4) to propose some measures in order to consolidate inclusive institutions in Romania, as to catch-up Poland in terms of economic development.

The motivation of our endeavour is deriving, first of all, from the precarious improvements registered by Romania in terms of sustainable economic development, despite its membership to the European Union for more than one decade. Second, there are few analyses applied to the case of Romania trying to explain the limited economic performances into the light of the NIE approach. Consequently, the novelty of our analysis is provided by at least three particular directions. First, we use the conceptual framework of the NIE when trying to define the sources of prosperity and apply them to the area of sustainable development. Second, we employ a comparative approach for two 
countries that have followed different transition profiles on their way to build a functional market economy and show that they are path dependent, in separate ways. Third, the original character of our paper is deriving from the mix of empirical methods that we have used, all of them applied for each country, in order to emphasize that inclusive institutions illustrate a must for sustainable development, and Poland is a good example from this perspective, while Romania should make harder efforts.

The remaining of the paper is structured as follows. Section 2 highlights the most relevant ideas depicted from the vast existing body of literature on the field of the nexus between sustainable development and institutions. Section 3 presents the methodology used to empirically validate our hypotheses. Section 4 presents the data sets that supported our investigations. Section 5 summarizes the results and discussions of our studies. Section 6 concludes.

\section{Literature review}

After the implosion of the USSR, the former countries were confronted with a complex challenge - transition towards capitalism. Two separate paths were followed in order to materialize transition: the shock therapy that implied a total restart of political, social and economic areas and the gradual therapy which implied lower social costs, but also weaker economic and social progresses. In both strategies building the metainstitution of democracy was paved with other subsequent requirements consisting in the establishment of the rule of law, private property and its extension - freedom, free competition or individualism (Pejovich, 2006; Rodrik, 2000). Only their rhythm and effectiveness were different. But, in order to have these inclusive economic institutions, inclusive political institutions were required. According to Acemoglu and Robinson (2016), democracy as meta institution is depending on state capacity associated with a large distribution of power within society. Consequently, those countries that were wealth oriented, like Poland, Hungary or the Czech Republic, were more likely to develop such political inclusive institutions than the power-oriented nations, such as Romania and Bulgaria (Weder, 2001; Balcerowicz, 1993), where the preservation of old political privileges and the concentration of political power into the hands of those whom designed transition were more important.

When discussing about inclusive institutions, we must state from the very beginning that they represent a result of political options. Consequently, if political institutions remained attached by the past values, they would have perpetuated the same inappropriate behaviours and captured all the privileges while fuelling poverty. In other terms, the path dependence phenomenon is manifesting and is harming prosperity (Kideckel, 2006; Kideckel, 2010). This was the case of Romania. There is a vast body of theory defining inclusive institutions. Acemoglu and Robinson (2012) define them as fair institutional framework based on rule of law, private property that foster the economic cooperation among individuals and, thus, prosperity. They provide equal chances for all the members of a society in terms of opportunities, social security, employment, civil rights, or access to resources (United Nations, 2016; Jakšić M \& Jakšić, M, 2018; Acemoglu \& Robinson, 2016; World Bank, 2013; Rodrik et al., 2004; Jütting, 2003). The positive impact of inclusive economic institutions is essential for promoting economic progress because 
they boost productivity growth and limit waste. Practically, these institutional arrangements are preconditions for sustainable development. On the contrary, extractive institutions will harm development (Adeyemi, 2012; Hassaballa, 2017; Leftwich \& Sen, 2010). In Poland reforms promoting inclusive institutions were designed since the 1980s, encouraging autonomy and the liberalisation of production activities, international trade, as well as financing investment projects. Moreover, here collectivization in agriculture never happened (Giannaros, 2007). In Romania, nothing like this was possible during communism, and after the 1990s progress was limited (Pop, 2007). The extractive political institutions gave birth to extractive economic institutions which severely harmed the economic development but enriched political elites. Practically, in Romania these extractive political and also economic institutions did not provide the necessary economic incentives as to enhance a healthy development. Corruption, excessive bureaucracy, poor rule of law, the unclear property rights were just few examples of institutional obstacles to development.

\section{Methodology}

In order to analyse the contribution of inclusive institutions - perceived as good and effective economic or political rules of the game - on the sustainable development process of Romania and Poland we have chosen, on one hand, a mix of analysis methods like Vector Error Correction Model, Variance decomposition, and Granger analysis and, on the other hand, variables such as: rule of law, government integrity, foreign direct investment as net inflows, and GDP per capita. All these were selected as to be able to provide us a relevant perspective upon the manner in which the process of building of a new institutional background, designed to sustain the market economy, was able to determine the rhythm and pace of development and prosperity in the two countries. We have focused on these two examples because Romania and Poland have followed two different transition paths, consequently, here the process of "creative destruction" of old political and economic institutions as to build new ones happened dissimilarly.

Our methodological approach was based on some important phases. First, to check if there is any existing relationship on the long run between the institutional component and the economic one, we have conducted the Johansen approach, followed by VECM. For this, we have selected Rule of law provided by Worldwide Governance Indicators of the World Bank and Government Integrity, a component variable of the Index of Economic Freedom provided by Heritage Foundation, as variables that emphasise the level of institutional effectiveness for both countries. When the economic development component was addressed, we have chosen the level of GDP per capita and Foreign direct investments (FDI) net inflows (BoP, current US\$), both provided by the World Bank. The former variables are having sufficient power to enclose the effectiveness of institutional transformation for the entire analysed period, and the latter set of variables are capturing the economic dynamics of the two states. So, we have chosen GDP per capita as our dependent variable for the model because it reflects the economic effectiveness and consequently a precise instrument of measuring economic growth around the world. As independent variables we have chosen $\mathrm{R} u l e$ of law, Government integrity and Foreign direct investments (FDI). The reason of this selection is based on the premise that FDI is higher for those countries were political and economic 
institutions are functioning properly - by promoting a stable and attractive environment for foreign investors - thus, contributing to the development of the host country. Why using VECM? Given the fact that most of the macroeconomic variables are trended, the problem of obtaining a spurious regression is highly likely to be present. In order to avoid such issue, VECM can be a solution, because if we have cointegration error correction models (ECMs) that are formulated in terms of first differences, trends from our variables will be removed and, thus, the problem of a potential spurious regressions disappears. According to the existing body of theory, in order to employ a VECM analysis, the selected variables must satisfy two conditions: (1) to be integrated in the same order and (2) must not be stationary in level. This second restriction is because VECM will automatically transform our data series into stationary ones, by applying the first difference (Asteriou, Hall, 2011, p. 370-371). Second, in order to determine the extent in which the variation of GDP per capita, as our dependent variable is relying on its own variance, we have conducted a Variance decomposition analysis. Furthermore, another advantage of such an investigation is the fact that it provides evidence upon which of our independent variables is able to influence in time the variability of the dependent variable. The relevance of this lies upon the fact that we are interested in pointing out that an impulse or innovation of solid and inclusive institutions or, on the contrary, of their poor quality can influence in the long-run, in a good or bad way, the variation of the GDP per capita. Third, we have chosen State Fragility Index and GDP per capita and we have employed a Granger causality analysis, as to determine whether there is a unidirectional or bidirectional relationship between these two variables on the short run. Practically, for each country we will conduct a VECM, Variance decomposition and Granger causality as to extract some relevant information concerning the impact of institutions (much or less inclusive) on the development's degree of health of the two nations.

\section{Data}

The timespan selected for our analyses is 1996-2018, given the limited availability of the data series for our variables. The dependent variable, GDP per capita (GDP_cap) provided by the World Bank, is an indicator that captures the economic state of productivity and development - preconditions for sustainability. As an indicator of economic effectiveness, this should be a result of inclusive institutions. The first independent variable is Rule of Law (RL) defined as "perceptions of the extent to which agents have confidence in and abide by the rules of society, and in particular the quality of contract enforcement, property rights, the police, and the courts, as well as the likelihood of crime and violence" (World Bank, 2020). The score of this indicator is ranging from -2.5 (poor) to 2.5 (performant). The second independent variable Government Integrity (GI) is retrieved from Heritage Foundation, being a component of the Index of economic freedom. It is highly linked with high level corruption, lack of morality of the policy makers, and has a negative impact on economic relations through raising uncertainty, and insecurity. The third independent variable, Foreign direct investment net inflows (BoP, current US\$) (FDI), is an indicator of the level of economic freedom and of the health and attractiveness of an economy. Concerning the Granger causality 
analysis, State Fragility Index (SFI) is an indicator that reflects the effectiveness and legitimacy of governmental policies and moreover, it represents the measures undertaken in order to materialise transition towards capitalism, for the ex-USSR nations, or general changes for the rest of the world. In other words, SFI is reflecting "state capacity to manage conflict, make and implement public policy, and deliver essential services, and its systemic resilience in maintaining system coherence, cohesion, and quality of life, responding effectively to challenges and crises, and sustaining progressive development" (Center for Systemic Peace, 2016, p.7). In some way it captures the level of economic, political, or social institutional inclusiveness, having values from 0 (no fragility) to 25 (maximum fragility). Not least, since the selected variables are expressed in different measurement units, the optimal transformation of our data was the logarithmic one.

Table 1. Descriptive analysis of variables for Romania and Poland

\begin{tabular}{|l|c|c|c|c|c|c|c|c|c|c|}
\hline & $\begin{array}{c}\text { GDP_C } \\
\text { AP_RO }\end{array}$ & FDI_RO & GI_RO & RL_R0 & $\begin{array}{l}\text { GDP_C } \\
\text { AP_PL }\end{array}$ & FDI_PL & GI_PL & RL_PL & SFI_RO & SFI_PL \\
\hline Mean & 6917.577 & 4944.876 & 35.33000 & 0.018892 & 10332.66 & 12817.30 & 48.21000 & 0.637519 & 0.565217 & 5.652174 \\
Median & 8447.610 & 4093.464 & 36.50000 & 0.014260 & 11979.68 & 13946.50 & 48.00000 & 0.659896 & 5.652174 & 5.000000 \\
Maximum & 12408.60 & 13667.82 & 50.00000 & 0.387541 & 15460.64 & 25031.00 & 70.00000 & 0.857506 & 0.000000 & 8.000000 \\
Minimum & 1633.010 & 263.0000 & 26.00000 & -0.260102 & 4140.980 & 795.0000 & 34.00000 & 0.404506 & 5.000000 & 3.000000 \\
Std. Dev. & 3553.434 & 3542.093 & 6.770377 & 0.191036 & 3921.897 & 6588.285 & 9.960496 & 0.157414 & 2.000000 & 1.897575 \\
Skewness & -0.355434 & 0.904270 & 0.480372 & 0.497697 & -0.444432 & -0.086986 & 0.311686 & -0.176733 & 8.000000 & 0.228746 \\
Kurtosis & 1.656091 & 3.185675 & 2.259139 & 2.328472 & 1.610220 & 2.079075 & 2.270310 & 1.558588 & 0.000000 & 1.447529 \\
Sum & 138351.5 & 98897.52 & 706.6000 & 0.377836 & 206653.3 & 964.2000 & 12.75038 & 256346.0 & 13.00000 & 130.0000 \\
\hline Obs. & 20 & 20 & 20 & 20 & 20 & 20 & 20 & 20 & 23 & 23 \\
\hline
\end{tabular}

As we can observe, we have a number of 20 observations for each variable, with the exception of SFI were the number is bigger, of 23. If we take a look at the GDP_cap, we can observe that in the case of Romania the difference between the mean value and the standard deviation is lower than in the case of Poland. This highlights that the distribution has a lower degree of homogeneity for Romania than for Poland. In other words, the picture points out that during the selected time-span of our analysis, 19962018, in Romania there were larger variations of the GDP per capita than in Poland, where the living conditions were from the very beginning better and more stable. The Polish economy has followed a more sustainable and homogenous evolution. Concerning the situation of government integrity, we may observe that Romania had a less virtuous government than Poland in the analysed period and less progress was made in this respect. Thus, Poland registered a higher degree of homogeneity in this regard. When the situation of rule of law and state fragility is addressed, the figures in the table reveal the same high degree of heterogeneity of data distribution for Romania. If we take a closer look at the data set, Romania registered even negative values for the Rule of law variable, thus, emphasising serious problems in terms of fair justice, the protection of private property, or effectiveness of courts. On the other side, Poland is placed in a much better position in this respect, showing a more homogenous distribution of data in the analysed interval. Practically, here, the shock transition managed to create some healthy institutional underpinnings as to support the market economy. The presence of more inclusive institutions in Poland is also pointed out by the state fragility index (SFI). 
The mean value is almost ten times higher than the one of Romania, while coefficient of variation is $33.75 \%$, which means a more homogenous distribution of data series and, therefore, a less fragile state. The descriptive statistics of the data has already revealed some serious disparities in terms of institutional effectiveness acquired during the transition process towards a market oriented economic system between the two countries; dissimilarities that will be further analysed following the proposed methodology.

\section{Results and discussions}

To see if we can perform the Johansen Cointegration Test, all the variables were previously checked for not being stationary in level, but in the first difference, using the Correlogram diagnostics and the ADF test. These tests indicated that this first condition was satisfied for both countries. Furthermore, the Akaike and Schwarz criterion from the unrestricted VAR have pointed out that we should take into consideration two lags for the analysis. In tables 2 we have summarized the Johansen cointegration test for Romania and in table 3 the results for Poland.

Table 2. Johansen Cointegration Test -

Romania

\begin{tabular}{|c|c|c|c|}
\hline \multicolumn{4}{|c|}{ Unrestricted Cointegration Rank Test (Trace) } \\
\hline $\begin{array}{l}\text { No. of } \\
\text { CE(s) }\end{array}$ & $\begin{array}{c}\text { Trace } \\
\text { Statistic }\end{array}$ & $\begin{array}{c}0.05 \\
\text { Critical Value }\end{array}$ & Prob. \\
\hline None* & 103.7909 & 54.07904 & 0.0000 \\
\hline At most $1 *$ & 58.50284 & 35.19275 & 0.0000 \\
\hline At most $2^{*}$ & 23.53924 & 20.26184 & 0.0171 \\
\hline At most 3 & 5.752190 & 9.164546 & 0.2108 \\
\hline \multicolumn{4}{|c|}{$\begin{array}{l}\text { Unrestricted Cointegration Rank Test } \\
\text { (Maximum Eigenvalue) }\end{array}$} \\
\hline $\begin{array}{l}\text { No. of } \\
\text { CE(s) }\end{array}$ & $\begin{array}{c}\text { Max-Eigen } \\
\text { Statistic }\end{array}$ & $\begin{array}{c}0.05 \\
\text { Critical Value }\end{array}$ & Prob. \\
\hline None* & 45.28806 & 28.58808 & 0.0002 \\
\hline At most $1 *$ & 34.96360 & 22.29962 & 0.0005 \\
\hline At most 2 & 17.78705 & 15.89210 & 0.0249 \\
\hline At most 3 & 5.752190 & 9.164546 & 0.2108 \\
\hline
\end{tabular}

Table 3. Johansen Cointegration Test - Poland

\begin{tabular}{|c|c|c|c|}
\hline \multicolumn{4}{|c|}{ Unrestricted Cointegration Rank Test (Trace) } \\
\hline $\begin{array}{l}\text { No. of } \\
\text { CE(s) }\end{array}$ & $\begin{array}{c}\text { Trace } \\
\text { Statistic }\end{array}$ & $\begin{array}{c}0.05 \\
\text { Critical Value } \\
\end{array}$ & Prob. \\
\hline None* & 65.74074 & 54.07904 & 0.0032 \\
\hline At most 1 & 32.11958 & 35.19275 & 0.1034 \\
\hline At most 2 & 15.92063 & 20.26184 & 0.1781 \\
\hline \multicolumn{4}{|c|}{$\begin{array}{c}\text { Unrestricted Cointegration Rank Test } \\
\text { (Maximum Eigenvalue) }\end{array}$} \\
\hline $\begin{array}{l}\text { No. of } \\
\text { CE(s) }\end{array}$ & $\begin{array}{l}\text { Max-Eigen } \\
\text { Statistic }\end{array}$ & $\begin{array}{c}0.05 \\
\text { Critical Value } \\
\end{array}$ & Prob. \\
\hline None* & 33.62116 & 28.58808 & 0.0104 \\
\hline At most 1 & 16.19895 & 22.29962 & 0.2843 \\
\hline At most 2 & 11.08727 & 15.89210 & 0.2454 \\
\hline
\end{tabular}

From the above two tables, we can observe that the cointegration analysis reveals a longrun relationship between the variables in the system. The figures from table 2 suggest that there are three cointegrating equations for the case of Romania, while the ones in table 3 indicate one cointegrating equation of Poland. Consequently, we can proceed to the next step of employing VECM for both countries.

The results of the estimated Vector Error Correction Model are presented in the following equation for the case of Romania:

D(LNGDP_CAP_RO $)=C(1) *($ LNGDP_CAP_RO(-1) - 0.964239978118*LNFDI_RO(-1) $0.694691834293)+\mathrm{C}(2) *($ LNGI_RO $(-1)-0.594539128163 *$ LNFDI_RO $(-1)+1.51789102647)$ $+\mathrm{C}(3) *($ LNRL_RO(-1) - 2.25660401807*LNFDI_RO(-1) + 20.5917288338$)+$ $\mathrm{C}(4) * \mathrm{D}(\mathrm{LNGDP}$ _CAP_RO(-1)) $+\mathrm{C}(5) * \mathrm{D}(\mathrm{LNGI} \mathrm{RO}(-1))+\mathrm{C}(6) * \mathrm{D}(\mathrm{LNRL}$.RO(-1)) + $\mathrm{C}(7) * \mathrm{D}\left(\mathrm{LNFDI} \_\mathrm{RO}(-1)\right)+\mathrm{C}(8)$ 
The R-Square is 0.768934 , meaning that GI, RL and FDI explain $76.89 \%$ the evolution of the Romanian GDP per capita. Furthermore, we can see that the coefficient of C1 is negative, -0.827778 , and statistically significant at a level of $5 \%(\mathrm{P}$ value $=0.0100$ ), meaning that there is a long-run causality running from GI, RL and FDI to the GDP per capita of Romania. Also, the P value of the model is 0.067630 , suggesting that the model is well fitted. Briefly, these results are validating the significant importance of economic and political institutions in determining economic dynamics.

For Poland, the equation of the model is represented as follows:

D $($ LNGDP_CAP_PL) $=$ C $(1) *($ LNGDP_CAP_PL $(-1)+2.40269672191 *$ LNGI_PL(-1) - 3.9798750409*LNRL_PL(-1) - 0.973008553722*LNFDI_PL(-1) - 11.4224443168 ) + $\mathrm{C}(2) * \mathrm{D}($ LNGDP_CAP_PL(-1)) + C(3)*D(LNGI_PL(-1)) + C(4)*D(LNRL_PL(-1)) + $\mathrm{C}(5) * \mathrm{D}(\mathrm{LNFDI} \mathrm{PL}(-1))+\mathrm{C}(6)$

Here the R-Square is lower, meaning that for Poland, the level of GDP per capita is influenced by GI, RL and FDI in proportion of $45.75 \%$. The coefficient of the C1 is also negative, -0.067946, and statistically significant at a level of $10 \%$ ( $\mathrm{P}$ value $=0.0588$ ), emphasising the long-run influence coming from GI, RL and FDI to the Polish GDP per capita. The $\mathrm{P}$ value of the model is 0.075846 , meaning that it is also well fitted. In this case the lower influence could be explained into the light of the effective institutional basis consolidated at the very beginning of the transition process that managed to create the necessary incentives for the proper functioning of the market economy. Poland has designed inclusive political and economic institutions, to wit, a more responsible and moral government that understood the incremental need of private property rights, a solid rule of law that protected both the citizens and the private sector. Consequently, the free market economy was functional, investors were attracted, and the government contributed to the long-run development of the country. Precisely the solid institutional underpinnings further expanded the positive externalities for the Polish economy and society, as a whole. On the contrary, for Romania the role of institutions is more important because here they lack effectiveness, so inclusive rules of the game are fundamentally required in order to rescue the country from the unstable path that is following governed by corruption, severe problems with rule of law, the lack of transparency in spending the public money, and the abusive use of public power as to enrich politicians into the detriment of the rest of society that remain deprived of resources, and human capital and with poor living standards. Our results are consistent with the ones of Castiglione et al. (2015) and Oto-Peralías \& Romero-Ávila (2017) that confirm the nexus between economic performance and legal institutions. The models for both countries were tested for Serial Correlation by using the LM test that pointed out no serial correlation and the heteroskedasticity Test Breusch-Pagan-Godfrey, which revealed no heteroskedasticity in the residual. The test checking for normality pointed out that the errors are normally distributed.

Table 4 illustrates the results of Variance decomposition of variables for Romania, while table 5 highlights Poland's situation. 
Table 4. Variance decomposition GDP_cap results - Romania
Table 5. Variance decomposition GDP_cap results - Poland

\begin{tabular}{|c|c|c|c|c|}
\hline Horizon & dlnGDP_CAP_RO & dlnGI_RO & dlnRL_RO & dlnFDI_RO \\
\hline 1 & 100.0000 & 0.000000 & 0.000000 & 0.000000 \\
\hline 2 & 86.70064 & 0.222933 & 5.937760 & 7.138668 \\
\hline 3 & 76.77856 & 1.321446 & 12.19481 & 9.705183 \\
\hline 4 & 68.72295 & 3.103226 & 17.38029 & 10.79353 \\
\hline 5 & 62.44739 & 5.212218 & 21.19010 & 11.15029 \\
\hline 6 & 57.66861 & 7.337273 & 23.81891 & 11.17520 \\
\hline 7 & 54.11038 & 9.272708 & 25.55296 & 11.06395 \\
\hline 8 & 51.51360 & 10.91442 & 26.65838 & 10.91360 \\
\hline 9 & 49.64925 & 12.23523 & 27.34632 & 10.76919 \\
\hline 10 & 48.32645 & 13.25617 & 27.76919 & 10.64819 \\
\hline
\end{tabular}

\begin{tabular}{|c|c|c|c|c|}
\hline Horizon & dlnGDP_CAP_PL & dlnGI_PL & dlnRL_PL & dlnFDI_PL \\
\hline 1 & 100.0000 & 0.000000 & 0.000000 & 0.000000 \\
\hline 2 & 90.05077 & 0.001407 & 8.897892 & 1.049932 \\
\hline 3 & 71.92519 & 0.192245 & 27.11953 & 0.763027 \\
\hline 4 & 56.49995 & 0.892559 & 41.56940 & 1.038085 \\
\hline 5 & 48.09577 & 2.010188 & 47.93076 & 1.963287 \\
\hline 6 & 44.68760 & 3.257600 & 49.02139 & 3.033405 \\
\hline 7 & 43.69702 & 4.277780 & 48.25632 & 3.768887 \\
\hline 8 & 43.76512 & 4.785042 & 47.47520 & 3.974646 \\
\hline 9 & 44.56497 & 4.812778 & 46.77009 & 3.852160 \\
\hline 10 & 45.93626 & 4.646951 & 45.70011 & 3.716679 \\
\hline
\end{tabular}

As pointed out in the above tables, for both cases, we may observe that within a 3-year horizon, an innovation or a shock applied to GDP_cap account for most in GDP_cap fluctuations. The rest of the variation is caused by the other explanatory variables. However, on a longer perspective, there are several differences between the two analysed countries. One lies in the fact that the GI and the FDI determine a larger fluctuation in the GDP_cap of Romania than in the Polish case, where the impact of these variables is quite modest. The other emphasise that an impulse applied to RL induce, over time, a larger variation in the case of GDP_cap of Poland as compared to the Romanian one. However, overall and once again, we can state that institutions matter in shaping the economic dynamics. Such results are definitely on the same wavelength with the New Institutional theory that stressed the major importance of good institutions, formal and informal, for determining a sustainable development. We can see that the case of Poland is consistent with our previous results, highlighting the fact the country is already benefiting of inclusive political institutions. The results are also consistent with the ones of Huberts (2018), according to which integrity is compatible with good governance, thus, with progress. What remains to be done as to further exploit the internal potential of healthy economic development relies on improving the incentives provided by economic institutions, to boost their inclusiveness as to expand prosperity of the country. From this perspective, Romania has much to learn from the example of Poland in terms of institutional transformation for catching-up other developing economies from the EU that have also shared the harmful USSR experience.

Tables 6 and 7 provide evidence with respect to the short-term Granger causality between economic development captured by GDP per cap and institutional quality highlighted by SFI for Romania and Poland. To run the Granger causality, data must be stationary in level, so we have applied the first difference only for GDP_cap, since SFI is already stationary in level. The results of the ADF tests are not provided here but are available by the authors upon the request. 
Table 6. Granger causality test Romania

\begin{tabular}{|l|l|c|}
\hline \multicolumn{2}{|l|}{ Null Hypothesis } & F-Statistic \\
\hline \multirow{4}{*}{ Lag=1 } & lnSFI_RO does not Granger Cause & 2.48784 \\
& dlnGDP_CAP_RO & $(0.0321)^{*}$ \\
\cline { 2 - 3 } & dlnGDP_CAP_RO does not Granger Cause & 0.05483 \\
& lnSFI_RO & $(0.8175)$ \\
\hline \multirow{2}{*}{ Lag=6 } & lnSFI_RO does not Granger Cause & 2.65282 \\
& dlnGDP_CAP_RO & $(0.2267)$ \\
\cline { 2 - 3 } & dlnGDP_CAP_RO does not Granger Cause & 22.5391 \\
& lnSFI_RO & $(0.0136)^{*}$ \\
\hline
\end{tabular}

Table 7. Granger causality test Poland

\begin{tabular}{|c|c|c|}
\hline \multicolumn{2}{|c|}{ Null Hypothesis } & F-Statistic \\
\hline \multirow{2}{*}{$\mathrm{Lag}=1$} & $\begin{array}{l}\text { lnSFI_PL does not Granger Cause } \\
\text { dlnGDP_CAP_PL }\end{array}$ & $\begin{array}{c}0.10765 \\
(0.0644)^{* *}\end{array}$ \\
\hline & $\begin{array}{l}\text { dlnGDP_CAP_PL does not Granger Cause } \\
\text { lnSFI_PL }\end{array}$ & $\begin{array}{l}0.00122 \\
(0.9743)\end{array}$ \\
\hline
\end{tabular}

As results highlight, both countries experience a unidirectional causality coming from the GDP_cap to SFI, on the short run for lag 1. In other terms, for Romania and Poland, the level of GDP per capita from one year ago can contribute to the variation of state fragility index, results being significant at the levels of $5 \%$ and $10 \%$, respectively. On the one hand, such result partially explains the institutionalist theory according to which there is a circularity relationship between the quality of regulations and the level of economic development. Institutions are a result that derives from the stage of prosperity of a certain economy, but they are also a determinant of further economic dynamics (Pohoață, 2009, p. 209). Consequently, our results validate the second theoretical assumption, in the sense that GDP per capita can cause SFI. On the other hand, for the case of Romania, we can observe that for lag 6, the level of state fragility can influence GDP per capita. This satisfies the first theoretical assumption, meaning that an improve of the quality of institutions can influence on the long run the economic output. Such results are on the same wavelength with theory because new regulations need time to be accepted, assimilated, and applied by the entire community as to generate positive externalities. We expected to see that the degree of a country's fragility could influence GDP per capita also for the case of Poland, but the analysis did not provided evidence in this respect.

\section{Conclusions}

In this paper we have analysed the impact of inclusive institutions, political and economic, on the economic development of Romania and Poland. Government integrity, rule of law and foreign direct investments were the selected variables tested in order to see if they can explain the level of GDP per capita, as a proxy indicator of economic development. On the one hand, integrity and mainly the one of the governments is able to determine the quality of governance and, consequently, the quality of political and economic institutions. But a country cannot create inclusive economic institutions when having problems with the integrity of its political leaders that focus more on the polarization of power in their own hands, than on creating the necessary incentives for encouraging development. On the other hand, the quality of rule of law is also an indicator of governance and institutional effectiveness, thus, it provides a proper feedback with respect to a country's affinity towards wealth or power. Also, FDI is a variable that can provide relevant information concerning the inclusiveness of 
economic institutions. Generally, foreign investors avoid those countries with extractive institutions and poor governance, given their associated higher transaction costs and uncertainty. For the particular cases of Romania and Poland, two countries that belonged to the USSR and have implemented two separate ways of materializing transition towards the market economy, these selected variables say much about the quality of institutions decanted during transition years. The analyses that we have employed are consistent with the existing body of literature in the field, validating the theory of path dependence, according to which the past experiences have a prominent influence on present economic evolution, and also on the future one, because of the inherited and prolonged codes of conduct, norms of behaviour, values, mentalities that define, in general, the artefactual structure of a society. These informal values, which are the most inflexible and rigid can guide as an "invisible hand" the economic dynamics of nations. The shock therapy implemented by Poland and the gradual transition applied by Romania have modelled different political and economic institutions. They were more inclusive for the case of Poland and rather extractive for Romania. The larger dispersion of political power among the Polish society provided by an upright political class, together with a solid rule of law, well defined property rights, freedom and fair competition determined a healthy long-run development of the country. For this case, our results are consistent with this perspective, showing that the aspect of government integrity is not an issue for sustainable development, while an improve of the rule of law can expand further economic output. Unfortunately, for Romania, precisely the rather extractive political institutions that maintained the power polarised into their own hands affected the institutional pillars of the market economy. The rule of law remained poor and unstable, property rights were unclearly defined, competition was limited, and all these affected the economic prosperity of the country on the long-term. Here we can observe the prominence of poor inclusive economic institutions even presently, after more than one decade of EU membership and, moreover, a limited progress in terms of sustainable development. Romania is a country that is still struggling with the lack of integrity of its politicians, corruption, low independence of justice, unfair competition, etc. As results have emphasised, an improvement of institutional quality (political and economic) can contribute to the enhance of development in the future, but, one might be aware that the economic results will appear on the long term, not immediately. Things are similar when debating the path dependence phenomenon, where the variance decomposition has once more pointed out, for the example of Romania, that a change in terms of institutional quality is able to determine a massive innovation in the level of GDP per capita. The results validate the theoretical background also for Poland, emphasising thus that here significant improvements were made, but it still can be done in terms of updating inclusive institutions at a higher level of performance as to produce positive externalities in terms of development.

The Granger causality has revealed that, on the short-run, GDP per capita can influence the average performance of political and economic measures undertaken by the governments in order to obtain prosperity. Such results for both countries partially validate the theoretical background of NIE, where a bidirectional relationship between institutions and development is stated. Such a relationship is validated for Romania, where an improvement of institutions can project on a 6 years horizon a higher GDP per 
capita. Consequently, our results support the research objectives of the paper and validate the thesis according to which countries governed by inclusive institutions are able to enhance and boost the long-term development, while countries guided by poor institutions (rather extractive than inclusive) suffer from limited development. The example of Romania may be helpful to depict some recommendation as to overcome those obstacles and to improve political and economic institutional inclusiveness. First, there should be more attention paid to human development (especially education and public health) that is essential to build a stronger society ready to react in front of political abuses. Second, the retainment of well-prepared labour force on the local labour market, civilised people willing to demand for democratic practices and transparency, are also important. Education makes people more responsible and much more aware of the existing choices that they have around them, and, in our opinion, this should be the key. The external governance model already exists, the UE providing it for the emerging economies, but this should be adapted to the specifics of each state and this could be a topic for our further research. As any research, our endeavour has some limitations: first, the limited number of countries taken into consideration for the analysis; second, the limited availability of data for the two countries.

\section{References}

Acemoglu, D. \& Robinson, J. (2012). Why nations fail: The origins of power, prosperity, and poverty, New York: Crown Publishers.

Acemoglu, D. \& Robinson, J. (2016). Paths to inclusive political institutions In: Eloranta J., Golson E., Markevich A., Wolf N. (eds) Economic History of Warfare and State Formation. Studies in Economic History. Springer, Singapore. Retrieved from https://doi.org/10.1007/978-981-101605-9_1 Accessed 18/06/2020

Adeyemi, O. O. (2012). Corruption and local government administration in Nigeria: a discourse of core issues. European Journal of Sustainable Development, 1(2), 183. Retrieved from https://doi.org/10.14207/ejsd.2012.v1n2p183. Accessed 19/06/2020

Asteriou, D., Hall, S.G. (2011). Applied Econometrics, Second Edition. Hampshire: Palgrave MacMillan.

Balcerowicz, L. (1993). Lessons and Consequences of the Letf's Victory in Poland: Interview, Transition Newsletter, World Bank, No.4.

Castiglione, C., Infante, D. \& Smirnova, J. (2015). Environment and economic growth: is the rule of law the go-between? The case of high-income countries. Energy, Sustainability and Society 5, 26. Retrieved from https://doi.org/10.1186/s13705-015-0054-8 Accessed 28/06/2020

Center for Systemic Peace (2016). State Fragility Index and Matrix. Retrieved from http://www.systemicpeace.org/inscr/SFImatrix2016c.pdf Accessed 15/06/2020

Giannaros, D. (2008). Twenty Years after the economic restructuring of Eastern Europe: An economic Review. International Business \& Economics Research Journal, 7(11): 35-48.

Hassaballa, H. (2017). Studying the Effect of Corruption on Income Per-capita Level in an IV Estimation in Developing countries. European Journal of Sustainable Development, 6(1), 57. Retrieved from https://doi.org/10.14207/ejsd.2017.v6n1p57. Accessed 19/06/2020

Hodgson, G.M (2006). “What Are Institutions?”, Journal of Economic Issues, Vol. XL (1): 1-25.

Huberts L. W. J. C. (2018). Integrity: What it is and Why it is Important. Public Integrity, 20:sup1, S18-S32, DOI: 10.1080/10999922.2018.1477404 Accessed 1/07/2020

Jakšić, M., Jakšić, M. (2018). Inclusive Institutions for Sustainable Development. Journal of Central Banking Theory and Practice, 1: 5-16.

Jütting, J. (2003). Institutions and Development: A Critical Review, Working Paper No. 20, OECD Development Center.

Kideckel, D.A. (2006). Colectivism şi singurătate în satele româneşti-Ţara Oltului în perioada comunistă şi în primii ani după revoluţie. Iaşi: Editura Polirom. 
Kideckel, D.A. (2010). România post-socialistă. Munca, trupul şi cultura clasei muncitoare, Iaşi: Editura Polirom.

Leftwich, A. \& Sen, K. (2010). Beyond institutions: Institutions and organizations in the politics and economics of poverty reduction - Thematic synthesis of research evidence. Research Programme Consortium for Improving Institutions for Pro-Poor Growth, Manchester: University of Manchester.

Retrieved from https://assets.publishing.service.gov.uk/media/57a08b00e5274a31e00008e8/8933_BeyondInstitutions-final.pdf Accessed 28/06/2020

North, D. C. (1990). Institutions, Institutional Change, and Economic Performance. Cambridge: Cambridge University Press.

Oto-Peralías, D. \& Romero-Ávila, D. (2017). Legal Reforms and Economic Performance: Revisiting the Evidence. Background Paper for the World Development Report 2017 "Governance and the Law. Retrieved from http://pubdocs.worldbank.org/en/193351485539892515/WDR17-BP-RevisitingLegal-Origins.pdf Accessed 29/06/2020

Pejovich, S. (2006). The uneven results of institutional changes in Central and Eastern Europe: the role of culture. Social Philosophy and Policy 23(1): 231-254.

Pohoață, I. (2009). Repere în economia instituțională. Bucuresti: Editura Economica.

Pop, L. (2007). Time and Crisis: Framing Success and Failure in Romania's Post-Communist Transformations. Review of International Studies, 33(3), 395-413. Retrieved from www.jstor.org/stable/40072184 Accessed 28/06/2020

Rodrik, D., Subramanian, A. \& Trebbi, F. (2004), Institutions rule: The primacy of institutions over geography and integration in economic development. Journal of Economic Growth, 9(2), 131-165, Retrieved from http://www.hks.harvard.edu/fs/drodrik/Research\%20papers/institutionsrule,\%205.0.pdf

Accessed 18/06/2020

Rodrik, D. (2000). Institutions for High Quality Growth: What they are and how to Acquire Them. Cambridge: National Bureau of Economic Research, Working Paper 7540.

United Nation. (2016). Global Sustainable Development Report 2016. New York: Department of Economic and Social Affairs. from https://sustainabledevelopment.un.org/content/documents/2328Global\%20Sustainable $\% 20$ deve lopment $\% 20$ report $\% 202016 \% 20$ (final).pdf. Accessed 21/06/2020

Veblen, T. B. (1992). The theory of the leisure class: An Economic Study of Institutions. New Brunswick (USA): Transaction Publishers.

Weder, B. (2001). Institutional Reform in Transition Economies: How far have they come. IMF. Retrieved from https://www.imf.org/en/Publications/WP/Issues/2016/12/30/Institutional-Reform-inTransition-Economies-How-Far-Have-they-Come-15148 Accessed 15/06/2020

World Bank (2013). Inclusion matters: The foundation for shared prosperity. Washington D.C.: World Bank.

World Bank (2020). Worldwide Governance Indicators. Retrieved from https://info.worldbank.org/governance/wgi/Home/Reports Accessed 10/06/2020

World Commission on Environment and Development (1987). Our Common Future. Retrieved from https://sustainabledevelopment.un.org/content/documents/5987our-common-future.pdf Accessed 11/06/2020 